\title{
PENGARUH MEDIA PEMBELAJARAN TERHADAP KETERAMPILAN MEMBACA PETA HURUF SISWA TAMAN TK NURUL AZIZI MEDAN
}

\author{
Epi Supriyani \\ Universitas Pembinaan Masyarakat Indonesia, Medan, Indonesia \\ episupsiregar1216@gmail.com
}

\begin{abstract}
Received: 25 November 2020 Membaca merupaka keterampilan bahasa tulis yang bersifat reseptif. Revised: 30 November 2020 Keterampilan membaca termasuk kegiatan yang kompleks dan Accepted: 01 Desember 2020 melibatakan berbagai keterampilan. Penelitian ini bertujuan untuk mengetahui perbedaan keterampilan membaca siswa Taman Kanak-kanak antara yang diberikan media petak huruf dibandingkan dengan yang diberikan pembelajaran media kartu huruf. Penelitian ini dilakukan pada siswa Taman Kanak-kanak Nurul Azizi Medan. Sampel penelitian ini terdiri dari 20 anak. Metode penelitian yang digunakan adalah quasi eksperimental desain factorial $2 \times 2$. Teknik analisis yang digunakan adalah dengan menggunakan uji-F, pengujian uji lanjut menggunakan uji Tuckey. Hasil penelitian menunjukkan bahwa terdapat perbedaan keterampilan membaca siswa Taman Kanak-kanak antara yang diberikan pembelajaran media petak huruf lebih baik bila dibandingkan dengan pembelajaran media kartu huruf pada taraf kepercayaan $\alpha=0,05$ dengan $\mathrm{F}_{\mathrm{h}}=17,54>\mathrm{F}_{\mathrm{T}}$ $=4,09$, dengan menggunakan uji Tuckey diperoleh $\mathrm{Q}_{\text {hitung }}=7,23>\mathrm{Q}_{\text {tabel }}=$ 3,96. Secara keseluruhan siswa Taman Kanak-kanak antara yang diberikan pembelajaran media petak huruf lebih baik bila dibandingkan dengan pembelajaran media kartu huruf.
\end{abstract}

Keywords: Media Pembelajaran; Keterampilan; Membaca

(*) Corresponding Author: $\quad$ Supriyani, episupsiregar1216@gmail.com, +62 85278311111

How to Cite: Supriyani, E. (2021). Pengaruh Media Pembelajaran Terhadap Keterampilan Membaca Peta Huruf Siswa Taman TK Nurul Azizi Medan. Research and Development Journal of Education, 7 (1), 50-59.

\section{INTRODUCTION}

Pemaparan yang di uraikan dalam (Kurikulum Standar Kompetensi TK dan RA, 2011) TK merupakan salah satu bentuk Pendidikan Anak Usia Dini yang ada di jalur Pendidikan Sekolah. Sebagaimana yang telah di tetapkan dalam Undang-undang Dasar sistem Pendidikan Nasional No. 20 Tahun 2003 ayat 3 yang menyatakan bahwa pendidikan anak usia dini pada pendidikan formal berupa Taman Kanak-kanak. Sesuai dengan Undang-undang Republik Indonesia tentang Pendidikan Nasional No. 20 Tahun 2003 pasal 3 Bab II yang menjelaskan bahwa tujuan pendidikan untuk mengembangkan potensi siswa agar mejadi berakhlak mulia, berilmu, kreatif, mandiri dan bertanggung jawab". Untuk mencapai tujuan tersebut diperlukan tenaga pendidikan yang profesional yaitu guru yang dapat memahami perkembangan anak, membimbing anak, menyusun dan melaksanakan program pembelajaran, menguasai metode serta mampu menyediakan dan menguasai media pembelajran. Melalui kegiatan pembelajaran diharapkan seluruh aspekaspek pengembangan anak dapat berkembang secara optimal sesuai dengan kurikulum Taman Kanak-kanak tahun 2009, aspek-aspek yang harus dikembangkan adalah pengembangan sosial, emosi, dan kemandirian. Pengembangan keterampilan dasar dapat dilihat bagian yakni keterampilan bahasa kognitif, fisik motorik dan seni yang bertujuan 
untuk 2 mengembaangkan keterampilan dasar yang diperlukan bagi siswa untuk melakukan pendidikan selanjutnya.

Proses menambah pengetahuan anak, salah satu keterampilan yang harus dikembangkan adalah keterampilan berbahasa yaitu membaca, karena dengan berbahasa anak dapat memahami kata dan kalimat. Menghubungkan dan memahami bahwa ada hubungan antara bahasa lisan dan tulisan pra membaca awal. Cara-cara yang bisa dikembangakan di TK Nurul Azmi Medan dalam persiapan membaca antara lain dengan menggunakan sarana pendukung berupa alat peraga atau alat permainan yang dapat digunakan oleh anak maupun guru dalam kegiatan pembelajaran. Penggunaan alat tersebut dapat menggunakan informasi atau menghasilkan pemahaman yang mendalam, memberi kesenangan serta membangkitan pengembanga imajinasi anak.

Pendidikan anak usia dini merupakan suatu upaya pembinaan yang diberikan kepada anak mulai dari sejak lahir sampai dengan usia 6 tahun. Yang diberikan rangsangan pendidikan untuk membantu pertumbuhan dan perkembangan jasmani dan rohani agar anak memiliki persiapan dalam memasuki pendidikan usia lanjut (UU Nomor 20 tahun 2003). Anak usia dini adalah individu yang berbeda, unik dan memiliki karakteristik sendiri sesuai dengan tahapan usianya. Oleh sebab itu pemberian rangsangan sebagai upaya pengembangan keterampilan bahasa sangat penting dilakukan karena bahasa merupakan alat penting dalam berinteraksi dengan lingkungan. Pendidikan anak usia dini adalah suatu masalah yang ditunjukkan kepada anak sejak lahir sampai dengan usia 6 tahun yang dilakukan melalui pemberian hipnotid dalam sebuah pendidikan untuk membantu pertumbuhan dan perkembangan secar jasmani dan rohani agar suatu asata anak memiliki kesiapan untuk memasuki pendidikan lebih lanjut dan produktif..

Pengembangan budaya baca tulis itu mutlak segera dilaksanakan. Pendidikan anak pra sekolah biasanya mampu mengembangkan suatu keterampilan bicara melalui percakapan yang dapat memikat hati orang lain. Anak dapat menggunakan dalam pemahaman bahasa dengan berbagai bnetuk dilakukan secara bertanya, berdiskusi dan sambal bernyanyi. Membaca adalah suatu proses perlakuan kognitif yang berupaya untuk menemukan berbagai bahan informasi yang terdapat dalam tulisan. Hal ini dapat diartikan membaca sebagai suatu proses cara berfikir untuk memahami suatu teks yang akan dibaca. (Dalman, 2013). Menurut Tzu dalam Ahmad Susanto (2011) mengatakan bahwa membaca adalah menerjemahkan suatu simbol (huruf) ke dalam bagian suara yang dikombinasikan dengan kata-kata. Hal ini di perkuat oleh Bond dalam Mulyono (2012) menggambarkan bahwa kegiatan ketermpilan membaca merupakan pengenalanberbagai simbol-simbol bahasa dan tulisan yang stimulus yang membantu proses mengingat tentang apa yang dibaca, untuk membangun suatu pengertian melalui pengalaman yang telah dimiliki.

Dari konsep paparan di atas peneliti menyimpulkan bahwa, membaca adalah suatu aktifitas pengenalan simbol yang diharapkan dapat menanggapi, mengingat dan dapat membangun pengertian melalui pengalaman dalam hidupnya.

Menurut Nurhadi (2010) memberi pemahaman bawa membaca adalah suatu kegiatan yang kompleks dan sulit untuk di aplikasikan. Kompleks adalah kegiatan yang dilakukan dalam membaca terlibat lansung dari berbagai faktor dalam dan factor luar pembaca. Faktor dalam dapat dilkukan dengan upaya intelegensi (IQ), minat, sikap, bakat, motivasi, tujuan keinginan membaca, dan lainnya. Faktor dalam diri anak bisa dilakukan dalam bentuk sarana membaca, teks bacaan (sederhana-berat, mudah-sulit), sedangkan faktor lingkungan masyarakat, atau faktor latar belakang keadaan sosial ekonomi, kebiasaan diri, dan tradisi adat dalam membaca. Sedangkan dilihat dari factor dalam dan luar ini saling berhubungan, membentuk sautu system semacam koordinasi yang rumit untuk menunjang pemahaman terhadap bacaan. Sedangkan Tarigan (2015) memberi pandangan bahwa kegiatan membaca merupakan hal yang menuntut 
keterampilan dari aspek berbahasa yang termasuk dalam bahasa tulis yang bersifat reseptif. Ada 3 konsep istilah yang palinh sering digunakan untuk memberikan komponen dasar dari proses membaca yaitu rekam, decoding, dan mengartikan. Rahim, (2011). Memberi pandangan bahwa merekam adalah salah satu kemampuan untuk mengumpulkan kata-kata dan kalimat, kemudian mengsosialisasikan dengan suara-suara sesuai dengan sistem tulisan yang dipergunakan, sedangkan kegiatan penyedian memberi gambran bahwa suatu proses penerjemahan rangkaian grafis ke dalam setiap kata-kata. Penekanan dalam membaca pada tahap ini ialah proses perseptual, yaitu pengenalan korespondensi rangkaian huruf dengan bunyi-bunyi bahasa. Sementara itu, proses memahami kata lebih ditekankan di kelas-kelas tinggi SD sedrajat.

Jika kita lihat dari hasil penelitian Dyah Uswatun (2017) menunjukkan bahwa keterampilan membaca siswa berdasarkan pada kelompok B di TK yang berada di SeKecamatan Pundong Bantul termasuk dalam kriteria baik/meningkat, dengan rata-rata perolehan skor sebesar 15,87. Pada kategori rendah sebanyak 6 anak $(3,28 \%)$, sedangkan untuk mulai berkembang bejumlah 32 siswa (17,49\%), sedangkan untuk berkembang yang sesui dengan harapan berjumlah 53 siswa $(28,96 \%)$, dan berkembang lebig bagus berjumlah 92 siswa $(50,27 \%)$. Hasil dari tes hipotesis keterampilan membaca memperolehan nilai yang signifikan sebesar 0,008 dimana lebih kecil daripada angka signifikan pada level yang sebesar 0.05, maka ditolak. JIka disimpulkan bahwa faktor gender menjadi salah satu faktor penting untuk menentukan keterampilan membaca siswa pada kelompok B di TK se-Kecamatan Pundong Bantul.

Menurut Wahyudin \& Mubiar (2012) "Pada rentang usia ini anak mengalami masa keemasan (the golden years) yang merupakan masa dimana anak mulai peka/sensitif untuk menerima berbagai rangsangan. Pada masa atau usia ini dapat juga dikatakan sebagai masa fundamenal bagi kehidupan anak selanjutnya, karena pada masa perkebangan ini otak sangat mempengaruhui dalam setiap perlakuan dengan sangat pesat sehingga anak mampu menerima informasi dengan sangat cepat. Tentunya unuk memaksimalkan perkembangan pada usia tersebut, maka anak usia dini perlu mendapatkan perhatian yang sangat extra dari lingkungan sekitar kehidupan anak.

Salah satu perkembangan yang sangat penting untuk diberikan anak usia dini adalah perkembangan bahasa anak. Bahasa sangat penting bagi kehidupan manusia tidak terkecuali anak usia dini terutama pada jaman yang semakin modern ini. Menurut Tom \& Harriet Sobol (2003) menyatakan bahwa diantara usia balita dan taman kanak-kanak, perkembangan bahasa anak merupakan hal yang fenomenal. Hal ini digambrakan oleh Gunara dalam A. Dariyo, (2007) bila kesempatan pada masa keemas an pada anak usia dini (golden age) ini tidak memperoleh rangsangan yang tepat, maka perkembangan bahasa anak cenderung tidak maksimal. Sebaliknya bila kesempatan ini dapat dimanfaatkan dengan baik dan orang tua memberi rangsangan yang tepat, maka masa kritis akan menghasilkan perkembangan bahasa yang maksimal.

Persepsi masyarakat, terdapat dua pendapat yang berbeda tentang, kapan mulai mengajarkan membaca kepada anak-anak. Apakah sejak Taman Kanak-kanak (TK) atau dimulai dari Sekolah Dasar (SD). Penelitian Durkin yang dikutip oleh Dhieni, dkk. (2005) memberi penyimpulan bahwa tidak ada satu efek pada anak-anak ketika membaca dini. Anak-anak yang telah diajar membaca sebelum masuk SD pada umumnya lebih maju di sekolah dari pada anak-anak yang yang belum pernah memperoleh materi membaca pada usia dini. Selanjutnya Piaget dalam Montolalu, dkk. (2005) mengemukakan bahwa anak usia 2-7 tahun berada pada fase praoperasioanl, anak sekarang sudah mulai menyadari bahwa pemahamannya terhadap sesuatu yang ada di sekelilingnya di sekitarnya tidak hanya dapat dilakukan melalui kegiatan berhadapan langsung, akan tetapi hanya dapat dikembangkan melalui kegiatan yang bersifat pada simbolis. 
Hainstock (2003) menyatakan bahwa perkembangan bahasa merupakan bagian yang integral dari proses belajardalam kegiatan membaca dan menulis. Ini sangat penting pada setiap kata-kata yang dikembangan setiap anak atau anak mampu berbicara dengan baik tidak diabaikan begitu saja, karena ini tidak lain adalah sarana yang sangat penting agar anak bisa mengetahui dan memahami pribadinya sendiri. Hal ini di perkut pendapat Vigotsky (McInnerney dan McInnerney, 1998:38-40) dalam Jamaris (2006), menjelaskan bahwa perkembangan bahasa pada anak yang berkaitan dengan perkembangan pada perlakuan kognitif. Sebagaiman di ungkapkan sebagai berikut:

a. Bagian Pertama, anak yang menggunakan kemampuan bahasa untuk melakukan komunikasi atau berbicara dengan orang lain. Keterampilan ini disebut dengan keterampilan bahasa di dalam dan menjadi dasar bagi keterampilan komunikasi kepada pribadinya. Pengaruh orang dewasa begitu penting dalam mengembangkan keterampilan bahasa pada anak secara eksternal. Orang dewasa memperkaya kosakata anak. Ia memberikan contoh tentang cara-cara berkomunikasi dengan bahasa yang baik dan benar.

b. Bagian Kedua, pada masa waktu transisi dari keterampilan berkomunikasi di luar keterampilan berkomunikasi secara internal membutuhkan masa yang begitu panjang. Peralihan ini terjadi pada waktu fase praoprasional, yakni pada masa usia 2-7 tahun. Selama masa ini, berbeicara anak pada diri sendiri merupakan bagian dari kehidupan. Ia akan berbicara dengan berbagai topik da tentang berbagai hal, melompat dari satu topik ke topik lainnya. Pada waktu anak sangat senang dalam bermain bahasa serta bernyayi. Pada usia 4-5 tahun, anak sudah dapat berbicara dengan bahasa yang baik, hanya sedikit kesalahan ucapan yang dilakukan anak pada masa ini.

c. Bagian Ketiga, pada waktu perkembangan berikutnya, siswa akan melakukan tindakan tanpa ada suatu batasan. Apabila siwa ini melakukan dengan menginternalisasi perkatan egosentris (berdasarkan sudut pandang pribadi) kedalam perkataan di dalam diri sendiri. Siswa ybanyak melakukan suatu kegiatan berkata-kata pada individu, yang dilanjutkan berkata di dalam individu lebih memiliki keterampilan sosial daripada siswa yang pada fase praoprasional kurang melakukan kegiatan tersebut. Papalia yang dikutip Dhieni, dkk. (2005) bahwa anak usia dini memberikan gambaran bahwa memperkaya huruf setiap kata-perkata melalui sistem pengulangan. Anak-anak yang melakukan pengulangan setiap kosa kata yang baru dan yang paling unik unik sekalipun mereka belum memahami artinya denga sepenuhnya. Dalam waktu mengembangkan kata-perkata pada kosa kata tersebut, perlu siswa membuat kartu fast mapping yang mana para siswa dapat melakukan kegiatan proses untuk menyerap arti kata baru setelah sekali atau dua kali dalam percakapan. Pada masa kanak-kanak awal lidah inilah anak mulai mengkombinasikan suku kata menjadi kata, dan kata lain menjadi kalimat.

Jenjang pendiidkan di TK pad hakikatnya merupakan wadah bagi perkembangan seluruh aspek keperibadian pada usia antara 4-6 tahun, yang direncanakan secara sistematis dan terprogram serta dikembangakan melalaui kegiatan "bermain sambal belajar" atau "belajar sambal bermain". Pada masa anak TK merupakan kegembiraan bagai kelangsungan anak usia dini untuk melakukan hal yang sifat aktif. Anak mempunyai dorongan alamiah untuk bermain menggunakan seluruh pancaindera dan keterampilannya. Dengan bermain anak mendapat kesempatan bereksperimen dan factor menemukan sendiri, sangat membantu memahami konsep-konsep sesuia dengan perkembangan anak.

Fenomena yang ada di TK Nurul Azmi Medan, sekolah TK yang melakukan metode pengajaran membaca dengan paksaan ini pun cukup marak. Bahkan beberapa sekolah TK ada pula yang konsepnya "bermain sambal belajar" tapi ujung-ujungnya tetap saja "belajar sambal bermain". Orang tua di TK Nurul Azmi Medan yang memiliki anak 
usia sekolah TK kerap bingung memilih sekolah dan bagaimana seharusnya bertindak. Disatu sisi kurikulum anak SD kelas 1 mengharuskan anak untuk sudah bis abaca. Di sisi lain, orang tua yang sadar dan tidak ingin memaksa anaknya, tetap dihadapkan pada tuntutan tersebut. Sehingga mau tak mau tetap saja mereka harus mengajarkan anaknya membaca. Dari kondisi tersebut, akhirnya banyak orang tua yang malah meminta guruguru TK Nurul Azmi Medan untuk mengajarkan ankanya memabacanya leawat les.

Masa usia TK pembelajaran dilakukan melalui bermain sambil belajar atau sebaliknya belajar sambil bermain. Banyak sekali metode bermain sambil belajar yang dapat dilakukan untuk mengenalkan huruf dan mengajarkan keterampilan membaca pada anak-anak. Penelitian ini penulis memilih dua metode pembelajaran yang dapat meningkatkan keterampilan membaca siswa TK, yaitu: Pertama, pembelajaran dengan menggunakan media petak huruf (bricks spelling), karena media pembelajaran media petak huruf merupakan media pembelajaran siap rancang untuk mengembangkan keterampilan membaca siswa Taman Kanak-kanak. Media petak huruf ini dipasarkan oleh kalangan khusus yang bergerak dalam penjualan alat-alat permainan Taman Kanakkanak. Dari informasi yang diterima peneliti media petak huruf dibeli oleh sekolah taman kanak-kanak, seperti: perguruan Sutomo medan, Methodist, Islam Fajar dan kalangan sendiri. Media petak huruf ini dibeli dalam jumlah sedikit oleh sekolah-sekolah tersbut. Kedua, media kartu huruf. Media petak huruf merupakan media pembelajaran yang memanfaatkan media siap rancang untuk mengembangkan keterampilan membaca siswa di Taman Kanak-kanak. Media petak huruf karakteristiknya berukuran panjang $=25 \mathrm{~cm}$ dan lebar $=25 \mathrm{~cm}$. Menerapkan pembelajaran media petak huruf, guru dapat melakukan langkah-langkah pengenalan, nyanyian, menyusun huruf vokal di petak huruf dan menyebutkan bunyi konsonan lalu menyusun di petak huruf.

Media pembelajaran kartu huruf merupakan pembelajaran konvensional yang biasa digunakan oleh guru di dalam kelas untuk mengembangkan keterampilan membaca siswa TK. kartu-kartu ini berukuran 5 × $5 \mathrm{~cm}$ dan bertuliskan huruf dikartunya. Penelitian Syari'ati Masyithoh (2016) menggambarkan bahwa keterampilan dalam bidang membaca awal dapat memberi peningkatan setelah memberi tindakan dengan menggunakan balok huruf, sehingga mempermudah siswa untuk membuat susnan huruf dengan cara diputar dan memberikan pada tantangan siswa yang dilakukan secara bersamaan dengan teman menyerupai perlombaan, serta memberikan upah secara menyeluruh yakni menggambarkan bintang pada bagian punggung telapak tangan siswa. Tri Lestari Waraningsi (2014) menyimpulkan bahwa keterampilan mendalami huruf anak kelompok A di TK Sulthoni Ngaglik Sleman dapat dikembangkan serta peningkatan dengan menggunakan media kartu kata dalam kegiatan proses pembelajaran permainan tebak huruf pada kartu kata dengan cara masing-masing anakmemegang kartu kata secara langsung dan memainkannya sesuai anjuran guru yaitu menyebutkan kata huruf, dan menunjukkan huruf, dan menghubungkan huruf. Data diperoleh bahwa terdapat peningkatan keterampilan memahami atau menguasai huruf di lihat pada waktu kondisi 1 besaran $29,2 \%$ dan dilihat pada Siklus I meningkat menjadi 58,3\%, dan sedangkan pada Siklus II mencapai besaran tingk $83,3 \%$.

Berdasrkan hal tersebut maka penulis menggunakan suatu media untuk digunakan dalam kegiatan belajar di TK Nurul Azmi Medan yakni media petak huruf dan media kartu huruf ini digunakan sedimikan mungkin rupa sebagai alat bermain sambal belajar dan dikemas dalam suatu media pembelajaran yang penyusunannya di landasi oelh perkembangan keterampilan membaca dan tingkat intelegensi anak TK. 


\section{METHODS}

Metode yang digunakan dalam penelitian ini adalah quasi ekskprimen. Menurut Ary, Jacobs dan Razavieh (1982) quasi eksperimen digunakan jika subjeknya penelitian tidak dapat dikendalikan secara penuh, seperri penelitain yang dilakukan di dalam kelas.Rancangan penelitian menggunakan desain faktorial $2 \times 2$. Tempat penelitian dilaksanakan di Taman Kanak-kanak Nurul Azizi Jalan STM/ Suka Elok No. 10 Medan, kecamatan Medan Johor, Kota Medan, Sumatera Utara. Prosedur dan Pelaksanaan perlakuan ini dilakuan dengan menggunakan yakni: 1) prosedur perlakuan; 2) pelaksaan perlakuan. Sedangkan pengontrolan perlakuan di lakukan dengan menggunakan: 1) validitas internal; 2) validitas eksternal. Teknik pengumpulan data dilakuakn dengan menggunakan tes.

\section{RESULTS \& DISCUSSION}

\section{Results}

\section{Keterampilan Membaca Siswa Taman Kanak-Kanak Yang Diberikan Pembelajaran Media Petak Huruf.}

Keterampilan membaca siswa di TK Nurul Azmi Medan untuk perlakuan pembelajaran denagn media petak huruf jumlah responden 20, untuk kelompok eksperimen didapat skor terendah $=10$ dan tertinggi $=25$. Rata-rata skor $($ mean $) \bar{x}=$ 18,35 , Varian $\left(\mathrm{S}^{2}\right)=17,50$ dan $(\mathrm{sd})=4,18$. Sedangkan nilai modus $(\mathrm{Mo})=21,50$ dan median $(\mathrm{Me})=21,50$. Berikut ini di sajikan tabel 1 distribusi frekuensi skor keterampilan membaca siswa di TK Nurul Azmi Medan yang diberikan pembelajaran media petak huruf sebagai berikut:

Tabel 1.

Keterampilan Membaca Pserta Didik TK Nurul Azmi Medan untuk Perlakuan Pembelajaran dengan Petak Huruf

\begin{tabular}{cccc}
\hline No. Kelas & Interval Kelas & F. Absolut & F. Relatif $(\%)$ \\
\hline 1 & $10-12$ & 2 & 10 \\
2 & $13-15$ & 3 & 15 \\
3 & $16-18$ & 5 & 25 \\
4 & $19-21$ & 5 & 25 \\
5 & $22-24$ & 4 & 20 \\
6 & $25-27$ & 1 & 5 \\
& Jumlah & $\mathbf{2 0}$ & $\mathbf{1 0 0}$ \\
\hline
\end{tabular}

Sumber: Pengolah Data SPSS 20

Berdasarkan tabulasi data yang diperoleh terhadap keterampilan membaca siswa Taman Kanak-kanak yang diberikan pelajaran media petak huruf pada tabel di atas dapat diuraikan bahwa 25\% skor responden berada di bawah rata-rata, dan 25\% responden berada pada rata-rata, sedangkan skor responden di atas rata-rata sebesar $50 \%$.

\section{Keterampilan Membaca Siswa Taman Kanak-Kanak Yang Diberikan Pembelajaran Media Kartu Huruf.}

Keterampilan membaca siswa di TK Nurul Azmi Medan untuk perlakuan pembelajaran denagn media petak huruf jumlah responden 20 , untuk kelompok 
kontrol didapat skor terendah $=9$ dan tertinggi $=20$. Rata-rata skor (mean) $\bar{x}=$ 14,60 , Varian $\left(S^{2}\right)=7,78$ dan sd $)=2,78$. Sedangkan nilai modus $(\mathrm{Mo})=21,50$ dan median $(\mathrm{Me})=21,50$.

Tabel 2.

Keterampilan Membaca Pserta Didik TK Nurul Azmi Medan yang diberikan Pembelajaran dengan Kartu Huruf

\begin{tabular}{cccc}
\hline No. Kelas & Interval Kelas & F. Absolut & F. Relatif $(\boldsymbol{\%})$ \\
\hline 1 & $9-10$ & 2 & 10 \\
2 & $11-12$ & 3 & 15 \\
3 & $13-14$ & 3 & 15 \\
4 & $15-16$ & 7 & 35 \\
5 & $27-18$ & 4 & 20 \\
6 & $19-20$ & 1 & 5 \\
& & $\mathbf{2 0}$ & $\mathbf{1 0 0}$ \\
\hline
\end{tabular}

Sumber: Pengolahan Data SPSS 20

Berdasarkan tabulasi data yang diperoleh terhadap keterampilan membaca siswa Taman Kanak-kanak yang diberikan pelajaran media petak huruf pada tabel di atas dapat diuraikan bahwa $40 \%$ skor responden berada di bawah rata-rata, dan 35\% responden berada pada rata-rata, sedangkan skor responden di atas rata-rata sebesar $25 \%$.

Hasil perhitungan analisis varians tentang perbedaan keterampilan membaca siswa Taman Kanak-kanak antara yang diberikan pembelajaran media petak huruf dan media kartu huruf, didapat hasil perhitungan $F_{h}$ sebesar 17,54 dan harga table $F_{1}$ untuk taraf siginifikan $\alpha$ sebesar 0,05 adalah 4,09 dengan derajat kebebasan $\mathrm{dk}$ (1:39) didapat $F_{h}=17,54>F_{t}=4,09$. Hasil analisis varians menunjukkan bahwa dari harga rata-rata tersebut terdapat perbedaan.

Berdasarkan hasil analisis statistic di atas dapat disimpulkan bahwa $\mathrm{Ha}$ diterima dan Ho ditolak. Artinya dapat disimpulkan bahwa terdapat perbedaan keterampilan membaca siswa Taman Kanak-kanak yang signifikan antara yang diberikan pembelajaran media petak huruf dibandingkan pembelajaran media kartu huruf pada taraf kepercayaan $\alpha=0,05$ teruji kebenarannya, sehingga Ho ditolak dan Ha diterima. Membaca permulaan di TK merupakan salah satu awal yang sangat penting dalam proses membaca karena hasilnya akan menjadi ilmiah untuk memahami konsep ilmu-ilmu yang amat luas, lebih khusus lagi untuk pengajaran bahasa (Dardjowidjojo, 1995).

Dardjowidjojo, (1995) menambahkan bahwa keterampilan membaca permulaan merupakan salah satu kunci keberhasilan karena dengan cara seperti itu, para siswa akan lebih mampu menggali informasi dari berbagai sumber tulisan. Dengan demikian, untuk membantu siswa Taman Kanak-kanak agar dapat meningkatkan keterampilan membacanya, berikanlah media pembelajaran petak huruf dengan metode bermain sambil belajar.

\section{Discussion}

Keterampilan Membaca Siswa Taman Kanak-Kanak antara Yang Diberikan Pembelajaran Media Petak Huruf dengan yang diberikan Pembelajaran Media Kartu Huruf. Hasil penelitian menunjukkan bahwa terdapat perbedaan keterampilan membaca pserta didik taman kanak-kanak antara siswa yang di ajar dengan pembelajaran media petak dan media kartu huruf, dimana skor rata-rata keterampilan membaca siswa taman 
kanak-kanak yang diajar dengan media petak huruf lebih tinggi dibandingkan dengan siswa yang diajar dengan media kartu huruf. Hal ini berindikasi bahwa media petak huruf lebih baik dalam meningkatkan pemahaman siswa tentang keterampilan membaca dibandingkan denagn media kartu huruf bagi siswa taman kanak-kanak pada taraf signifikan 5\%. Hasil ini menunjukkan bahwa untuk mengajarkan materi ajar tentang membaca lebih baik menggunakan media petak huruf dibandingkan dengan pembelajaran dengan media kartu huruf.

Membaca adalah suatu aktivitas dalam kegiatan untuk memperoleh pengertian dari kombinasi beberapa huruf dan kata. Hasil penelitian Juel ((1988) memberi gambaran bahwa membaca adalah proses perlakuan untuk mengenal setiap kata demi kata dan memadukan antara satu dengan yang lain artinya dengan kata dalam kalimat dan struktur setiap bacaan. Hal ini di perkuat oleh hasil penelitian Jo Lique Tjoe (2013) menunjukkan bahwa kemmapuan membaca awal TK B meningkat melalui pemanfaatan Multimedia. Proses pembelajaran melalui Multimedia terdiri dari huruf membaca, kata-kata dan kalimat sederhana dengan menggunakan variasi yang menarik dari metode dan strategi pengajaran. Sedangkan hasil penelitian Tatik Ariyati (2014) memberi hasil bahwa keterampilan membaca di awal anak TK kelompok B memakai media gambar dapat meningkat. Analisis data ini dicapai dari membandingkan data prasiklus dan pascasiklus.

Penelitian Arizqa Yasirli Salik (2019) memberi gambaran secara detail bahwa pada keterampilan membaca awal antara kelompok eksperimen dengan kelompok kontrol sebelum ada keterampilan media kartu huruf yang memeberi berpengaruh yang signifikan terhadap keterampilan membaca awal anak di kelas A TK Wijaya Kusuma Taman Sidoarjo. Hasil penelitian Nining Handini (2017) Mengacu pada kenyataan bahwa tingkat keterampilan membaca anak TK kelas B sebelum kegiatan membaca dilakukan melalui permainan kartu kata tingkat membaca tergolong rendah, namun sesuai dengan pelaksanaan pembelajaran dengan permainan kartu kata terjadi peningkatan. Hasil research ini mengambarkan bahwa yang diinginkan, dengan ketermapilan permaianan kartu kata dapat mneingkatkan keterampilan membaca anak usia dini.

Berdasarkan hasil penelitian di atas dapat kita simpulkan bahwa keterampilan pesrta didik untuk mengekspresikan diri (lisan maupun tertulis) dapat dikembangkan melalui pengalaman nyata pserta didik, yang diunkapkan melalui kegiatan menggambar dan bercerita dengan menggunakan kata-kata dari anak itu senndiri.

\section{CONCLUSION}

Berdasarkan hasil pengujian hipotesis seperi yang telah di uraikan penelitian ini menyimpulkan bahwa:

1. Terdapat perbedaan keterampilan mengdeklamasi siswa TK Nurul Azmi Medan antara yang diberikan pembelajaran media petak huruf dengan pembelajaran media huruf dengan kata lain keterampilan mengdeklamasi siswa TK Nurul Azmi Medan antara yang diberikan pembelajaran media petak huruf lebih baik bila dibandingkan dengan pembelajaran media kartu huruf.

2. Terdapat interaksi antara media pembelajaran dalam mempengaruhi keterampilan membaca siswa TK Nurul Azmi Medan, dengan melihat hasil penelitian bahwa bagi kelompok pesrta didik dengan pembelajaran media petak huruf.

\section{IMPLICATION}


Berdasarkan temuan penelitian di atasa dapat di ambil implikaisi bahwa temuan media pembelajaran petak huruf lebih tinggi dari media pembelajaran kartu huruf dalam mengembangkan keterampilan membaca siswa TK Nurul Azmi Medan. Keterampilan membaca siswa TK Nurul Azmi Medan memberiak petunjuk bahwa dalam pembelajaran membaca, media petak huruf lebih tepat untuk di terapkan daripada media kartu huruf. Penerepan media pembelajaran petak huruf dalam pembelajaran membaca berimplikasi terhadap perencanaan dan pengembanagn metode pembelajaran membaca bagi siswa TK Nurul Azmi Medan dengan tingkat kematangan kognitif yang terbatas meliputi: 1) pengaturan desai awal pembelajaran; 2) strategi pengubahan tingkah laku; 3) orientasi pembelajaran; dan 4) penyesuian materi pembelajaran.

\section{REFERENCES}

Dalman. (2013). Keterampilan Membaca. Jakarta: Raja Grafindo Persada.

Dariyo A. (2007). Psikologi Perkembangan Anak Tiga Tahun Pertama. Bandung: Refika Aditama.

Depdiknas . (2003) Undang-Undang RI No.20 Tahun 2003.Tentang Sistem Pendidikan Nasional.

Depdiknas. (2009). Peraturan Menteri Pendidikan Nasional Republik Indonesia Nomor 58 Tahun 2009 Tentang Standar Pendidikan Anak Usia Dini. Jakarta: Depdiknas.

Dhieni, N., dkk. (2005). Metode Pengembangan Bahasa. Buku Materi Pokok. Jakarta: Pusat Penerbitan Universitas Terbuka.

Dyah Uswatun (2017) Perbedaan Keterampilan Membaca Anak Kelompok B Berdasarkan Gender di TK Se-Kecamatan Pundong Bantul. Skripsi. Yogyakarta: Universitas Negeri Yogyakarta.

Hainstock, E.G., (2002). Teaching Montessori in The Home Pre-School Years. (Judul: Montessori untuk Pra Sakolah. Alih Bahasa:Hermes). Jakarta: Pustaka Delapratasa.

Jamaris, Martini. (2006). Perkembangan dan Pengembangan Anak Usia Taman KanakKanak. Jakarta : Grasindo. Jakarta. PENSA : Jurnal Pendidikan dan Ilmu Sosial Volume 1, Nomor 1, Agustus 2019; 139-152 https://ejournal.stitpn.ac.id/index.php/pensa. 5-7.

Jo Lioe Tjoe, (2013) Peningkatan Keterampilan Membaca Permulaan Melalui Pemanfaatan Multimedia (Action Research, Kelompok B TK. Kristen Anugerah Jakarta, Tahun 2012) PAUD PPs Universitas Negeri Jakarta. JURNAL PENDIDIKAN USIA DINI Volume 7, Edisi 1 April 2013. 1-3.

Juel, C. (1988). Learning to Read and Write : A Longitudinal Study of 54 Children from First Through Fourth Grade. Journal of Educational Psychology, 80 (4), 437-447.

Masyithoh Syari'ati, (2016) Meningkatkan Kemampuan Membaca Permulaan Melaluimedia Balok Huruf Pada Kelompok B Tk Negeri Pembina Bantul. Jurnal Pendidikan Anak, Volume 5, Edisi 2, Desember 2016. 798.

Montolalu, B.E.F., (2005). Bermain dan Permainan Anak. Buku Materi Pokok. Jakarta: Pusat Penerbitan Universitas Terbuka.

Mulyono Abdurrahman, (2012) Anak Berkesulitan Belajar,Jakarta: Rineka Cipta.

Nining Handini (2017) Meningkatkan Keterampilan Membaca Anak Usia Dini Melalui Kegiatan Permainan Kartu Kata Di Tk Al-Fauzan Desa Ciharashas Kecamatan Cilaku Kabupaten Cianjur. Jurnal EMPOWERMENT Volume 6, Nomor 1 Februari 2017, ISSN No. 2252-4738.19.

Nurhadi (2010) Bagimana Meningkatkan Keterampilan Membaca, Bandung: Sinar Baru Algesindo.

Rahim, F. (2011). Pengajaran Membaca di Sekolah Dasar. Jakarta: Bumi Aksara. 
Salik Yasirli Arizqa (2019) Pengaruh Media Kartu Huruf Terhadap Keterampilan Membaca Awal Di Kelas A Taman Kanak-Kanak (Tk) Wijaya Kusuma Taman Sidoarjo. Skripsi. Surabaya: UIN Sunan Ample

Susanto Ahmad, (2011) Perkembangan Anak Usia Dini Pengantar Dalam Berbagai Aspeknya, Jakarta: Kencana Predana Media Group.

Tarigan, Henry Guntur, dkk. (2015). Membaca Sebagai Suatu Keterampilan Berbahasa. Bandung: Angkasa.

Tatik Ariyati (2014) Peningkatan Keterampilan Membaca Permulaan Melalui Penggunaan Media Gambar. PAUD PPs Universitas Negeri Jakarta. JURNAL PENDIDIKAN USIA DINI Volume 8 Edisi I, April 2014. 1-2.

Tom \& Hariet Sobol (2003). Rancangan Anak Cerdas. Jakarta: Inasasi Perss

Tri Lestari Waraningsih (2014) Upaya Meningkatkan Keterampilan Mengenal Huruf Menggunakan Media Kartu Kata Di Tk Sulthoni Ngaglik Sleman. Skripsi. Yogyakarta: Univesitas Negeri Yogyakarta.

Wahyudin U \& Agustin, M. (2012). Penilaian Perkembangan Anak Usia Dini. Bandung: Refika Aditama. 